\title{
Yield of Sesame (Sesamum indicum L.) as Influenced by Organic Fertilizers in the Southern Guinea Savanna of Nigeria
}

\author{
I. M. Haruna (Corresponding Author) \& M. S. Abimiku \\ Department of Agronomy, Nasarawa State University \\ P.M.B. 1022, Keffi, Nigeria
}

Tel: 234-803-968-3552_E-mail: ibrahimmharuna@yahoo.com

Received: November 27, $2011 \quad$ Accepted: December 17, $2011 \quad$ Published: February 1, 2012

doi:10.5539/sar.v1n1p66

URL: http://dx.doi.org/10.5539/sar.v1n1p66

\begin{abstract}
Field experiments were carried out during the rainy seasons of 2008 and 2009 at the teaching and research farm of Nasarawa State University, Keffi, Lafia campus in the southern Guinea savanna agro-ecological zone of Nigeria to assess the effects of poultry manure, cow manure and sheep manure on the performance of sesame crop. Manure application was found to have significantly increased both yield and yield attributes of sesame compared with non application at all. Application of $2.5 \mathrm{t} \mathrm{ha}^{-1}$ of poultry manure produced the highest value for all the yield attributes measured. The seed yield per hectare in both years were also optimized with the application of $2.5 \mathrm{t} \mathrm{ha}^{-1}$ of poultry manure (1914.07 and $1933.20 \mathrm{~kg} \mathrm{ha}^{-1}$ in 2008 and 2009 respectively) compared with any other applied rates of sheep and cow manure and is therefore recommended.
\end{abstract}

Keywords: Number of capsules, Capsule weight, Seed yield per plant, Seed yield per hectare, Sheep manure, Poultry manure, Cow manure

\section{Introduction}

Sesame (Sesamum inducum L.) also known as beniseed in West Africa, Sim-sim in East Africa is an oil crop belonging to the family Pedaliaceae grown in both tropical and sub-tropical regions of Africa, Asia and Latin America. It is the most important crop from which semi-drying vegetable oils are obtained and perhaps the oldest crop cultivated for its oil (Onwueme \& Sinha, 1991). In 2007, Asia produced 2.4 million metric tons; Africa produced 1.2 million metric tons and Nigeria 110,000 metric tons of sesame (UN/FAO, 2008).

Sesame is produced mainly in the savanna agro-ecological zones of Nigeria by small holders' farmers on relatively poor soils with limited inputs, thereby resulting in low average yield of $300 \mathrm{~kg} \mathrm{ha}^{-1}$ compared with $1,960 \mathrm{~kg} \mathrm{ha}^{-1}$ in Venezuela and 1,083 $\mathrm{kg} \mathrm{ha}^{-1}$ in Saudi Arabia respectively (Abubakar et al., 1998).

Sesame oil is considered to be of high quality oil and is often referred to as the "queen" of vegetable oil. This is due to its stability and high keeping quality as well as resistance to rancidity. Sesame oil is used in the production of paints, soaps, cosmetics, perfumes, insecticides, canned sardine and canned beef as well as for pharmaceutical and ethno botanical uses (FAO, 2002; RMRDC, 2004). The whole seed is high in calcium, phosphorous, iron and are well supplied with essential vitamins such as thiamin, riboflavin and niacin. The whole seed is used on top buns and snack foods, fried and eaten with sugar, unfried or ground and used in making soup. The leaves are used for vegetable soup (Onwueme and Sinha, 1991).

Traditional sesame growers in Nigeria rarely apply fertilizer on this crop because it is considered that it perform well even on poor soils (Haruna \& Usman, 2005). However, nutrition studies in the tropics have shown that the crop perform well with the applications of organic or inorganic fertilizers (Olowe \& Busari, 2000; Okpara et al., 2007; Haruna et al., 2011).

Manure is a key fertilizer in organic and sustainable soil management. It contains many of the elements that are needed for plant growth and development. Apart from increasing soil fertility, manure serve as soil amendment by adding organic matter to the soil. Organic manure has also been reported to greatly improve water holding capacity, soil aeration, soil structure, nutrient retention and microbial activity (Anon, 2007a) Manure application results in increased $\mathrm{pH}$, water holding capacity and decrease in bulk density when used on long term basis (Anon, 2006). 
Considering the low yield of sesame obtained in most growing areas as a result of non application of fertilizers and the poor fertility status of savanna soils, there is the need to assess the performance of sesame using different organic manure, which is the objective this study seeks to achieve.

\section{Materials and Methods}

Field Experiments were conducted during the rainy seasons of 2008 and 2009 at the Teaching and Research Farm of Nasarawa State University, Keffi, Lafia campus in the southern Guinea savanna agro-ecological zone of Nigeria $08^{\circ} 30^{\prime} \mathrm{N}$ and $30^{\prime} \mathrm{E}, 18 \mathrm{~m}$ above sea level. The soil of the experimental site is sandy loam, well drained characterized by moderate $\mathrm{pH}(5.0-6.0)$, low in organic matter $(0.06-0.07 \%)$, available phosphorus $(10.5-$ $11.1 \mathrm{ppm})$ and nitrogen $(0.03-0.05 \%)$. The plot had not been cropped for three years.

The experiment consisted of factorial combinations of three levels each of sheep manure $\left(0,2.5\right.$ and $\left.5 \mathrm{tha}^{-1}\right)$, poultry manure $\left(0,2.5\right.$ and $\left.5 \mathrm{t} \mathrm{ha}^{-1}\right)$ and cow manure $\left(0,2.5\right.$ and $\left.5 \mathrm{t} \mathrm{ha}^{-1}\right)$ respectively. The twenty seven (27) treatment combinations were laid out in a split-plot design and replicated three times. Cow and poultry manure levels were assigned to the main-plot, while sheep was assigned to the sub-plot. The gross plot size was $18 \mathrm{~m}^{2}$ $(4.5 \mathrm{~m} \times 4 \mathrm{~m})$ while the net plot size was $9 \mathrm{~m}^{2}(3 \mathrm{~m} \times 3 \mathrm{~m})$. The experimental area was disc-ploughed and harrowed twice to a fine tilt. This was then followed by ridging at $75 \mathrm{~cm}$ apart (between rows) and the field marked into plots and replications. The plots were separated by $1.0 \mathrm{~m}$ unplanted boarder while replications were separated by $2.0 \mathrm{~m}$ unplanted boarder. The organic fertilizers were incorporated two weeks before sowing.

The planting material used was Ex-Sudan; it is white in colour, of medium height and medium maturity ( 85 to 90 days) (RMRDC, 2004). Sesame was planted on the $29^{\text {th }}$ and $30^{\text {th }}$ August in 2008 and 2009 respectively. Six to ten seeds of sesame were sown at $15 \mathrm{~cm}$ intra-row spacing on ridges spaced $75 \mathrm{~cm}$ apart and was later thinned to two plants per stand at three weeks after sowing. Manual hoe weeding was done at 3,6, and 9 WAS to keep the experimental plots weed-free.

The crop was harvested at physiological maturity when the leaves and the stems changed colour from green to yellow with a reddish tint on them. Harvesting was manually done with the aid of a sickle by cutting the plants at the base close to the ground. Plants from each net plot were placed in a sack to dry so as to minimize seed loss when capsule dehisces. When the harvested plants were adequately dried, the sacks were gently beaten with sticks in order to release all the seeds from the capsules. The seeds were then separated from the chaff by winnowing. Ten randomly selected plant samples from each plot were used at harvest to determine the yield attributes such as number of capsule per plant, capsule yield per plant, seed yield per plant while, the entire plant in the net plot were used to obtain the seed yield per hectare.

\subsection{Data Analysis}

The data collected were subjected to analysis of variance using the ' $F$ ' test to estimate the significance in the effects of the treatments as described by Snedecor and Cochran (1967). Comparisons of treatment means were done using Least significant difference.

\section{Results}

Data on the yield attributes comprising of the number of capsules per plant, capsule weight per plant, seed yield per plant, 1000 seed weight at harvest showed that application $2.5 \mathrm{t} \mathrm{ha}^{-1}$ of poultry manure produced significantly higher number of capsules per plant, capsule weight per plant, seed yield per plant compared with other rates of applied poultry manure and other manure types used (Table 1). Increasing the rate of applied poultry manure from $2.5 \mathrm{t} \mathrm{ha}^{-1}$ to 5.0 significantly decreased all the yield attributes measured. Applications of $5 \mathrm{tha}^{-1}$ of cow and sheep manure significantly increased number of capsules per plant, capsule yield per plant, seed yield per plant and 1000 seed weight compared with other rates of application.

Seed yield per hectare of sesame was significantly increased by the application of $2.5 \mathrm{tha}^{-1}$ of poultry manure in 2008 and 2009 compared with other rates of applied manure (Table 2). Applications of $5 \mathrm{tha}^{-1}$ of cow and sheep manure produced significantly higher sesame yield per hectare compared with zero and application of $2.5 \mathrm{tha}^{-1}$ in 2008 and 2009. In both years of study, the highest yield of sesame per hectare (1914.07 and 1933.20 in 2008 and 2009 respectively) was produced by the application of $2.5 \mathrm{t} \mathrm{ha}^{-1}$ of poultry manure. Interactions between the treatments tested, were however, not significant.

\section{Discussion}

From the results obtained, it was seen that yield and yield attributes of sesame were significantly increased by the application of poultry manure, cow and sheep manure. This could be attributed to the low nutrient status of the soil and the ability of manures to supply nutrients contained in them gradually to support crop growth which 
later translated to high yield and yield attributes (Aliyu, 2003 \& Anon., 2007a). Both yield and yield attributes of sesame were optimized at $2.5 \mathrm{tha}^{-1}$ of poultry manure application while, optimum yield were obtain with the applications of the highest applied rate of cow and sheep manure probably because the poultry manure used during the experiment has higher nutrient content compared with cow and sheep manure (Table 3).

Application of poultry manure produced the highest yield of sesame compared with sheep and cow manure. This could be attributed to the fact that poultry manure has a low carbon to nitrogen ratio which mineralizes faster to release its nutrients hence its effect was superior to other manure tested.

\section{Conclusion}

From the fore going, it can be concluded that though both yield and the yield attributes of sesame were significantly increased with the applications of all the nutrients tested compared with non application at all, application of $2.5 \mathrm{t} \mathrm{ha}^{-1}$ of poultry manure produced the highest yield and yield attributes in both years and is therefore recommended.

\section{References}

Abubakar, S. S., Onyibe, J. E., \& Tologbonshein, E. B. (1998). The role of extension Research and information dissemination in enhancing beniseed production Production, marketing of resource poor farmers. Proceedings of the First Workshop on Beniseed held at the National Cereal Research Institute, Badegi, Nigeria, March $3^{\text {rd }}-5^{\text {th }}$, 1998. Pp86-9.

Agboola, A. A., \& Omueti J.A.I. (1982). Soil fertility problems and its management in Tropical Africa. International conference on land clearing and Development. 11 to Ibadan 23-26 November 1982, 49.

Aliyu, L. (2003). Effect of nitrogen and phosphorus on the chemical composition and Uptake of mineral elements by pepper (Capsicum annum L.). Crop Research, 25(2), 272-279.

Anonymous. (2006). Fertilizer use by crops in Zimbabwe, FAO/UN, Rome. 55.

Anonymous. (2007a). Effect of organic and inorganic nutrient sources on soil mineral Nitrogen and maize yields in Western Kenya. http://www.agnet.org

Bonsu, O. K. (2003). Effect of spacing and fertilizer application on the growth, yield and yield components of sesame (Sesamum indicum L.). Journal of Sustainable Agric., 23(1), 40-49

Deshmukh, M. R., Jain, H. C., Duhoon, S. S., \& Goswami, U. (2002). Integrated nutrient Management in sesame fir kymore plateau zone of M.P. Journal of Oilseeds Research, 19(1), 73-75.

Duhoon, S. S., Jyotishi, A., Deshmukh, M. R., \& Singh, N.B. (2004). Optimization of sesame (Sesamum indicum L.) production through bio/natural inputs. http://www.cropscience.au/res

Duncan, D. B. (1955). Multiple ranges and multiple F-tests. Biometrics, 11, 1-42. http://dx.doi.org/10.2307/3001478

FAO (Food and Agriculture Organization of the United Nations. (2002). Sesame Production Information. http://www.ecoport.org/EP.exeSEntFull?ID=1937

Haruna, I. M., \& Usman, A. (2005). Agronomic practices that enhances increased yield and seed quality of sesame (Sesame indicum L.). A paper presented at the: Agric. Transformation Day (sesame and rice) organized by OLAM Nig. Ltd. Held atAgro Millers Ltd. Compound, Uni-Agric. Road, Makurdi, $4^{\text {th }}$ Feb., 2005.

Haruna, I. M., Ibrahim, H., \& Rahman, S. A. (2009). The yield and Profitability of Roselle. (Hibiscus sabdarifffa L.) At varying poultry manure and nitrogen Fertilizer rates in the Northern guinea Savanna of Nigeria. Electronic Journal Of environmental and food chemistry. 8(11), 1136-1139.

Maritus CHT, PLG. Vlelc. (2001). The management of organic matter in tropical Soils: what are the priorities? Nutrient cycling in Agro-ecosystems, 61, 1-16. http://dx.doi.org/10.1023/A:1013347027853

Ojeniyi, S. O. (2000). Effect of goat manure on soil nutrients and okra yield in a rain forest area of Nigeria. Applied Tropical Agriculture, 5, 20-23.

Onwueme, I. C., \& Sinha, T. D. (1991). Field crop production in Tropical Africa. The Netherlands. 480pp.

RMRDC. (2004). Report on survey of Agro-Raw Materials in Nigeria Beniseed. Raw Materials research and development council, Abuja. 99.

Snedecor, G. W., \& W. G. Cochran. (1990). Statistical Methods. $8^{\text {th }}$ ed., Iowa state Univ., Press, Ames, Iowa, U.S.A. 
UN/FAO. (2008). Regional sesame production, trade and consumption. United Nation /Food and Agriculture Organization. 5.

Table 1. Effect of treatments on the number of capsules per plant, capsule yield per plant, seed yield per plant and 1000 seed weight (data pooled for 2008 - 2009)

\begin{tabular}{ccccc}
\hline Treatment & $\begin{array}{c}\text { Number of } \\
\text { capsules per plant }\end{array}$ & $\begin{array}{c}\text { Capsule yield per } \\
\text { plant }(\mathrm{g})\end{array}$ & $\begin{array}{c}\text { Seed yield per } \\
\text { plant }(\mathrm{g})\end{array}$ & $\begin{array}{c}1000 \text {-seed weight } \\
(\mathrm{g})\end{array}$ \\
\hline Poultry manure t ha ${ }^{-1}$ & & & & \\
0 & $28.57 \mathrm{c}$ & $12.94 \mathrm{c}$ & $10.21 \mathrm{c}$ & $3.10 \mathrm{~b}$ \\
2.5 & $49.65 \mathrm{a}$ & $19.95 \mathrm{a}$ & $15.24 \mathrm{a}$ & $3.50 \mathrm{a}$ \\
5.0 & $36.40 \mathrm{~b}$ & $15.64 \mathrm{~b}$ & $12.48 \mathrm{~b}$ & $3.25 \mathrm{~b}$ \\
S.E \pm & 0.449 & 0.353 & 0.114 & 0.066 \\
Cow manure t ha ${ }^{-1}$ & & & & \\
0 & $35.77 \mathrm{c}$ & $14.29 \mathrm{c}$ & $11.20 \mathrm{c}$ & $3.10 \mathrm{~b}$ \\
2.5 & $37.28 \mathrm{~b}$ & $15.93 \mathrm{~b}$ & $12.72 \mathrm{~b}$ & $3.26 \mathrm{~b}$ \\
5.0 & $41.57 \mathrm{a}$ & $18.31 \mathrm{a}$ & $13.99 \mathrm{a}$ & $3.47 \mathrm{a}$ \\
S.E \pm & 0.449 & 0.353 & 0.114 & 0.066 \\
0 & & & & \\
Sheep manure t ha ${ }^{-1}$ & $37.07 \mathrm{c}$ & $14.34 \mathrm{c}$ & $11.77 \mathrm{c}$ & $3.12 \mathrm{~b}$ \\
2.5 & $37.98 \mathrm{~b}$ & $15.48 \mathrm{~b}$ & $12.88 \mathrm{~b}$ & $3.25 \mathrm{~b}$ \\
5.0 & $39.57 \mathrm{a}$ & $18.71 \mathrm{a}$ & $13.27 \mathrm{a}$ & $3.48 \mathrm{a}$ \\
S.E \pm & 0.432 & 0.354 & 0.098 & 0.055 \\
\hline
\end{tabular}

Means followed by different letters within the same treatment group or column are statistically different at $5 \%$ level of probability.

Table 2. Seed yield $\left(\mathrm{kg} \mathrm{ha}^{-1}\right)$ of sesame as influenced by organic manure in 2008 and 2009

\begin{tabular}{|c|c|c|}
\hline \multirow{2}{*}{ Treatment } & \multicolumn{2}{|c|}{ Grain yield (kg/ha) } \\
\hline & 2008 & 2009 \\
\hline \multicolumn{3}{|c|}{ Poultry manure $\left(\mathrm{t} \mathrm{ha}^{-1}\right)$} \\
\hline 0 & $1134.35 \mathrm{c}$ & $1191.06 \mathrm{c}$ \\
\hline 2.5 & $1914.07 \mathrm{a}$ & $1933.20 \mathrm{a}$ \\
\hline 5.0 & $1339.35 b$ & $1406.32 b$ \\
\hline $\mathrm{SE}+$ & 3.416 & 3.587 \\
\hline \multicolumn{3}{|c|}{ Cow-dung manure $\left(\mathrm{t} \mathrm{ha}^{-1}\right)$} \\
\hline 0 & $1318.05 \mathrm{c}$ & $1383.95 \mathrm{c}$ \\
\hline 2.5 & $1416.60 \mathrm{~b}$ & $1487.43 b$ \\
\hline 5.0 & $1653.13 \mathrm{a}$ & $1669.13 \mathrm{a}$ \\
\hline $\mathrm{SE}+$ & 3.416 & 3.587 \\
\hline \multicolumn{3}{|c|}{ Sheep manure $\left(\mathrm{t} \mathrm{ha}^{-1}\right)$} \\
\hline 0 & $1173.32 \mathrm{c}$ & $1231.99 \mathrm{c}$ \\
\hline 2.5 & $1581.40 \mathrm{~b}$ & $1660.47 b$ \\
\hline 5.0 & $1633.05 \mathrm{a}$ & $1649.38 \mathrm{a}$ \\
\hline $\mathrm{SE}+$ & 2.373 & 2.492 \\
\hline
\end{tabular}

Means followed by different letters within the same treatment group or column are statistically different at $5 \%$ level of probability.

Table 3. Composition of organic manure used during the experiment

\begin{tabular}{ccccccccccc}
\hline \multirow{2}{*}{ Manure type } & & & & & & & & 2009 & \\
& & $\% \mathrm{P}$ & $\% \mathrm{~K}$ & $\% \mathrm{Ca}$ & $\% \mathrm{Mg}$ & $\% \mathrm{~N}$ & $\% \mathrm{P}$ & $\% \mathrm{~K}$ & $\% \mathrm{Ca}$ & $\% \mathrm{Mg}$ \\
\hline Poultry manure & 3.00 & 1.76 & 2.30 & 3.72 & 0.58 & 3.83 & 1.93 & 2.54 & 3.54 & 0.55 \\
Cow manure & 1.74 & 0.40 & 1.10 & 0.30 & 0.40 & 1.32 & 0.38 & 1.11 & 0.30 & 0.40 \\
Sheep manure & 1.9 & 1.4 & 2.9 & 0.25 & 0.30 & 1.81 & 1.50 & 2.75 & 0.22 & 0.31 \\
\hline
\end{tabular}

